\title{
Peran Komunikasi Pemerintahan dalam Penanganan Lingkungan Kumuh
}

\author{
Indriyati Kamil \\ Universitas Langlangbuana, Jalan Karapitan No.116, Lengkong, Bandung \\ Email: R_indriya@yahoo.com
}

\begin{abstract}
Abstrak. Kelurahan Linggar adalah salah satu desa di Kecamatan Rancaekek Kabupaten Bandung dengan kategori kumuh yang cukup tinggi serta minim fasilitas infrastruktur. Salah satu faktor penyebab kekumuhan di Desa Linggar adalah tercemarnya area sungai dan pesawahan oleh sampah dan limbah pabrik. Pembuangan Limbah Cair (PLC) yang dihasilkan oleh industri mengakibatkan pencemaran dan kerusakan masif pada sungai dan ratusan hektar area pertanian Oleh karena itu, diperlukan strategi operasional yang tepat untuk menangani masalah pencemaran yang terjadi di Desa Linggar. Hasil penelitian menunjukkan bahwa komunikasi pemerintahan Kepala Desa Linggar dilakukan dengan menggunakan sinergi platform kolaborasi, pemda desa linggar menggunakan prinsip keterbukaan dan transparansi dalam menjalin koordinasi dan jejaring komunikasi dengan pihak pemangku kepentingan diantaranya pemerintah pusat, propinsi,kabupaten-kota, dunia usaha, dan masyarakat untuk menangani masalah pencemaran dan kerusakan lingkungan. Pemerintah Daerah Linggar berupaya mendorong sektor industri untuk melaksanakan tanggung jawab lingkungan dengan mengurangi dampak pencemaran akibat limbah industri dan secara berkesinambungan memberikan perlindungan lingkungan di area pemukiman dan lahan penduduk. Komunikasi juga dilakukan Pemda Desa Linggar dengan menfasilitasi perencanaan prasarana lingkungan, juga pemukiman dengan menggunakan konsep community action plan (CAP) atau rencana tindak komunitas, penguatan kelembagaan masyarakat dengan membentuk paguyuban Warga Peduli Lingkungan (Pawapeling), membuat media warga serta melakukan fokus group diskusi kelompok terarah.
\end{abstract}

Kata kunci : komunikasi pemerintahan, sinergi platform kolaborasi, transparansi, dan penguatan kelembagaan

Abstract : Linggar Urban Village is one of the villages in Rancaekek sub-district of Bandung Regency with a fairly high slum category and lack of infrastructure facilities. One of the causes of the slums in Linggar village is the contaminated river and paddy fields by garbage and factory waste. Therefore, appropriate operational strategies are needed to address the environmental issues. The result of the research shows that communication of Linggar village government is done by using synergy of collaboration platform, linggar village government using principles of openness and transparency in coordination and communication network with stakeholders such asthe government of central, provincial, district-city, business, and society. Linggar local government seeks to encourage the industrial sector to carry out environmental responsibility by reducing the impact of pollution due to industrial waste and continuously providing environmental protection in residential areas and community land. The communication is also done by the local government of linggar village by facilitating the planning of environmental infrastructure, also the settlement by using the concept of community action plan (CAP), strengthening the community institution by forming community association of Pawapeling, making citizen media and directed focus group discussion

Keywords : government communication, synergy of collaboration platform, transparency, and institutional strngthening 


\section{PENDAHULUAN}

Pembangunan bidang lingkungan yang berhubungan dengan tempat tinggal beserta sarana dan prasarananya memang perlu mendapatkan prioritas mengingat tempat tinggal merupakan salah satu kebutuhan dasar (basic need) manusia. Sudah selayaknya pembangunan lingkungan permukiman itu pemerintah mengeluarkan peraturan perundangundangan tentang lingkungan yang dimaksudkan untuk memberikan arahan (guide line) bagi pembangunan sektor lingkungan dan permukiman.

Salah satu landasan yang digunakan oleh pemerintah untuk meningkatkan peran kelembagaan dalam pembangunan permukiman dan lingkungan adalah Undang-Undang Nomor 4 Tahun 1992 tentang Perumahan dan Permukiman. Undang-Undang ini menyebutkan bahwa perumahan berfungsi sebagai lingkungan tempat tinggal atau lingkungan hunian yang dilengkapi dengan prasarana dan sarana lingkungan, sedangkan pemukiman adalah bagian dari lingkungan hidup di luar kawasan hutan lindung, baik yang berupa kawasan perkotaan maupun kawasan pedesaan yang berfungsi sebagai lingkungan tempat tinggal atau lingkungan hunian dan tempat kegiatan yang mendukung perikehidupan dan penghidupan.

Hal yang sering muncul dalam masalah penanganan lingkungan kumuh adalah lemahnya kemampuan Pemerintah Daerah dalam memainkan peran penting untuk meningkatkan kualitas hidup masyarakat. Pemerintah Pusat dan Pemerintah Daerah harus bekerja sama dalam membangun komunikasi untuk mengatasi lingkungan kumuh sebagai prioritas. Hal ini disebabkan keterbatasan dan kapasitas pemerintah daerah saat ini yang masih kurang optimal dalam penanganan lingkungan kumuh sehingga peran pemerintah pusat masih sangat dibutuhkan.
Lingkungan kumuh yang muncul di daerah perkotaan karena Pemerintah tidak memiliki kebijakan, peraturan perundang-undangan dan sistem penyediaan lingkungan dan perumahan yang menguntungkan masyarakat berpenghasilan rendah, sehingga Pemerintah Daerah harus dapat memiliki inisiatif sendiri untuk menangani lingkungan, terutama daerah kumuh.

Masalahnya, hanya sedikit Pemerintah Daerah yang mampu dan mau memperbaiki kualitas hidup di daerah kumuh. Pelajaran dari praktik lapangan di beberapa kota menunjukkan bahwa 'political will' diperlukan untuk mengatasi masalah ini. Bentuk 'political will' yang dibutuhkan adalah fondasi yang kuat, berjalan dalam jangka panjang sehingga bisa berkelanjutan dan berskala besar (pendekatan di seluruh kota). Namun, 'political will' juga harus didukung dengan memobilisasi potensi dan kapasitas semua pemangku kepentingan yang ada termasuk di masyarakat.

Keberhasilan yang sedang berlangsung di lapangan menunjukkan bahwa mempertahankan kemauan politik dan komitmen yang kuat akan mendukung keberhasilan penanganan permukiman kumuh. Dalam menghadapi masalah lingkungan dan permukiman kumuh, pemerintah harus mengkomunikasikan kepada masyarakat setiap program di wilayahnya.

Pemerintahan yang berfungsi dalam memberikan pelayanan kepada masyarakat dipengaruhi oleh keberlangsungan komunikasi yang dijalankan tersebut. Adanya komunikasi atau interaksi yang berjalan lancar kepada masyarakat memberikan dampak positif terhadap eksistensi pemerintah di Indonesia. Interaksi langsung yang terjadi antara pegawai dan masyarakat disebabkan adanya kondisi atau lingkungan pekerjaan yang mendukung. 
Dengan komunikasi, kita membangun kebersamaan dengan membentuk sebuah kontak dalam hubungan. Ini berarti individu saling memberikan informasi, pemikiran dan sikap dalam hubungan. menjelaskan bahwa komunikasi sebagai proses berbagi atau menggunakan informasi bersama dan hubungan antara peserta dalam proses informasi (Kincaid dan Schramm dalam Arifin, 2008). Selain itu komunikasi juga bisa diartikan sebagai proses menghubungi atau menjalin hubungan dengan menggunakan bahasa, gerak tubuh, tubuh, sistem, isyarat, kode dan lain-lain.

Pemerintah dalam menyampaikan pesan pembangunan harus memiliki kredibilitas, daya tarik, kesamaan dalam hal kebutuhan, harapan dan perasaan sehingga masyarakat dapat dipengaruhi untuk mengikuti keinginan pemerintah sehingga pembangunan dapat dilaksanakan.

Komunikasi memiliki sejumlah pengaruh baik pada jenis, tujuan, tugas pemerintahan termasuk pemeliharaan hubungan. Dengan tidak adanya fasilitas untuk hubungan komunikasi ke semua arah dalam sebuah kegiatan, akan sulit untuk mengetahui apa yang telah dicapai, apa yang akan dicapai dan bagaimana hambatan dalam pelaksanaan kerja dan komunikasi merupakan sumber informasi bagi para pemimpin dalam menginformasikan berbagai kebijakan atau penanganan lingkungan.

Meningkatkan akses terhadap infrastruktur dan layanan dasar di daerah kumuh untuk mendukung terwujudnya permukiman yang layak huni, produktif dan berkelanjutan adalah tujuan yang ingin dicapai oleh Pemerintah Daerah, kemudian diterjemahkan ke dalam skala mikro untuk menciptakan lingkungan dan pemukiman yang layak huni di tingkat desa khususnya Desa Linggar. Untuk mencapai tujuan tersebut, serangkaian kegiatan di tingkat kabupaten / kota dan tingkat desa / kelurahan disinergikan dengan platform "Kolaborasi".

Tujuan di atas, yang diterjemahkan ke dalam dua kegiatan, yaitu pencegahan dan peningkatan kualitas permukiman, dilakukan melalui pendekatan partisipatif yang menyatukan perencanaan makro (top down) dan perencanaan mikro (bottom up) dengan menempatkan masyarakat sebagai subyek pembangunan dan pengambil keputusan akhir dengan pemerintah daerah dan pemangku kepentingan lainnya.

Penelitian ini berlokasi di Desa Linggar. Linggar adalah desa di Kecamatan Rancaekek Kabupaten Bandung. Terdapat 15 kampung yang berada dalam wilayah Kelurahan Desa Linggar. Secara umum kondisi fisik Desa Linggar merupakan salah satu desa terluas di banding desa yang lain yang ada di Wilayah Kecamatan Rancaekek,yaitu mencapai 351,385 ha meliputi darat : 115,775 ha, dan sawah : 235,650 ha.

Desa Linggar juga dilewati oleh dua buah sungai kecil, yaitu sungai Cimande dan sungai Cikijing yang merupakan anak sungai dari sungai Citarik yang nantinya bermuara ke sungai Citarum. Namun sayang, kedua sungaitersebut sudah sangat kotor dan tercemar oleh sampah, bahkan salah satu dari kedua sungai tersebut dijadikan sebagai tempat pembuangan limbah tekstil PT.Kahatex yang mengakibatkan air sungainya menjadi berwarna hitam pekat dan berbau tidak sedap. Hal tersebut membuat areal pesawahan Rancakeong menjadi tidak produktif lagi, karena sumber pengairan persawahan berasal dari sungai yang telah dicemari oleh limbah tekstil tersebut. Inilah yang mengakibat kondisi lingkungan di Desa Linggar menjadi kumuh.

\section{METODE}

Metode penelitian yang digunakan 
dalam penelitian ini adalah metode kualitatif dengan pendekatan analisis deskriptif. Penelitian deskriptif dapat diartikan sebagai prosedur pemecahan masalah yang diteliti dengan mendeskripsikan keadaan objek atau subjek penelitian (seseorang, institusi, masyarakat, dll) pada saat ini, berdasarkan fakta-fakta yang muncul seperti apa adanya (Hadari, Nawawi, 1998). Isu penelitian deskriptif dalam masyarakat serta prosedur yang berlaku di masyarakat dan situasi tertentu, termasuk hubungan, aktivitas, sikap, pandangan, dan proses yang berkelanjutan dan dampak dari suatu fenomena.

Penelitian ini dilakukan di lokasi sasaran program penanganan wilayah kumuh yaitu Desa Linggar Kecamatan Rancaekek Kabupaten Bandung. Informan dalam penelitian ini ditentukan dengan menggunakan purposive sampling, berdasarkan kriteria-kriteria tertentu yang telah dipertimbangkan dan sebagaimana menurut Kriyantono (2007) kriteria informan dipertimbangkan agar dapat mendukung tujuan penelitian. Tujuan dari penelitian ini tidak lain menjawab pertanyaan-pertanyaan penelitian yang sudah disampaikan pada bagian sebelumnya

Informan dalam penelitian terdiri atas Kepala Desa beserta aparat, petugas dirjen PU, tokoh masyarakat, dan pihak industri yang ditentukan berdasarkan purposive sampling.

\section{HASIL DAN PEMBAHASAN}

Masyarakat Desa Linggar Kecamatan Rancaekek merupakan masyarakat agraris dan mayoritas warganya adalah petani, dengan kondisi lingkungan pertanian yang asri, produksi padi dan ikan melimpah. Di kawasan tersebut mengalir sungai kecil, dikenal dengan nama Sungai Cikijing, sebagai sumber air untuk sawah dan kolam ikan serta untuk keperluan rumah tangga lainnya, dengan debit yang tidak terlalu besar. Debit air ini meningkat setelah melewati kawasan pabrik karena adanya pembuangan limbah cair. Tanpa disadari, peningkatan debit air sungai tersebut rupanya merupakan awal rusaknya kondisi lingkungan Desa Linggar yang berkepanjangan.

Menurut penelitian Greenpeace Asia Tenggara dan Walhi Jabar 2015, sawah yang tercemar di Kawasan Rancaekek seluas 1.215 hektar, ditambah 727 hektar saat banjir. Hal ini menyebabkan produktivitas sawah menurun 1-1,5 ton per hektar tiap musim. Kerugian mencapai Rp3,65 miliar per tahun. Wacana pemerintah mengalihfungsikan dan membeli lahan produktif yang terpapar limbah bahan berbahaya dan beracun (B3) di Rancaekek bukan merupakan langkah yang tepat. Alih fungsi sawah menjadi kawasan industri bukan merupakan sebuah solusi dan tidak sesuai dengan semangat pemerintah untuk mewujudkan swasembada pangan.

Walaupun episentrum persoalannya terjadi di 4 (empat) desa, persoalan tersebut sudah tembus hingga aras pusat kekuasaan lingkungan hidup. Permasalahan pencemaran kerusakan lingkungan di Kec. Rancaekek, Kabupaten Bandung, khususnya di 4 (empat) desa, yaitu: Jelegong, Linggar, Bojongloa, dan Sukamulya, sudah berlangsung lebih dari 20 tahun. Hal inilah yang menjadi pekerjaan rumah Pemda, Kepala Desa beserta perangkatnya dalam mencari solusi keberlanjutan pembangunan bidang lingkungan.

Kerusakan lingkungan dan terbentuknya kawasan kumuh Desa Linggar Kecamatan Rancaekek berawal dari pembangunan industri di Kecamatan Cikeruh, Kabupaten Sumedang. Berbagai perusahaan telah membentuk cluster industri yang sebagian besar menghasilkan limbah cair dan membuangnya ke badan air sungai 
Cikijing. Dari puluhan perusahaan di sekitar Jalan Raya Rancaekek, yang berada dekat Desa Linggar, terdapat 3 Perusahaan yaitu: PT. Kahatex, PT. Insan Sandang dan PT Five Star, yang proses produksinya maupun debit limbah cairnya diduga memberikan konstribusi signifikan terhadap peningkatan beban pencemaran sungai Cikijing. Karena tidak ada sumber air lainnya, air yang sudah tercemar berbagai bahan kimia (termasuk logam berat) tetap dipergunakan untuk mengairi sawah dan kolam ikan, bahkan dipakai juga untuk mandi, cuci dan memasak.

Luas areal pertanian dan perikanan yang terkena dampak pencemaran lingkungan \pm 415 hektar. Jumlah penduduk di Desa tersebut lebih dari 10.000 orang. Terjadinya pencemaran lingkungan diindikasikan dengan menurunnya kualitas lahan pertanian dan menyebabkan menurunnya produksi, bahkan menyebabkan kematian tanaman padi atau bulir padinya hampa dan ikan yang dibudidayakan mati. Tidak hanya pencemaran tanah dan air tetapi juga menyebabkan kawasan tersebut dilanda banjir saat musim hujan datang. Agar para petani tidak dirugikan, serta produksi pertanian dan perikanan tidak menurun, yang diakibat pencemaran sungai Cikijing, maka pemerintah daerah melakukan penindakan tegas terhadap industri industri yang tidak mengoperasikan instalasi pengolahan air limbah (IPAL) nya sesuai dengan ketentuan.

Dampak lainnya adalah kesehatan, terdapat indikasi kuat bahwa pencemaran di kawasan tersebut telah menyebabkan meningkatnya berbagai penyakit. Persoalan pencemaran lingkungan, yang semula hanya berdimensi teknis, telah berkembang ke dimensi sosial, hukum, ekonomi, kesehatan, keamanan, bahkan politik dan budaya.

\section{Komunikasi Pemerintahan Berbasis Sinergi Platform Kolaboratif}

Komunikasi pemerintahan hendaknya dapat menyesuaikan dengan perkembangan pemerintahan yang saat ini berubah, dari government (penyelenggaraan pemerintahan) ke governance. Dalam hal ini terjadi perubahan interaksi dari kekuasaan dan kontrol menjadi pertukaran informasi, komunikasi dan persuasi dengan penyediaan informasi kepada masyarakat untuk dapat mengawal pemerintah. Ketika masyarakat semakin skeptis dengan pemerintah, maka komunikasi pemerintahan yang berbasis kearifan lokal harus diperkuat untuk menjaga kepercayaan. Komunikasi tanpa mempedulikan persoalan persoalan yang mendasar dalam masyarakat, tidak akan memberikan hasil yang diharapkan. Persoalan konflik yang terjadi sangatlah kompleks karena tidak hanya menyangkut persoalan politik semata, tetapi juga persoalan ekonomi, sosial, dan budaya.

Pengertian komunikasi pemerintah dalam arti menggabungkan dua arti komunikasi dan pemerintahan, definisi komunikasi pemerintah adalah penyampaian gagasan, program dan gagasan pemerintah kepada masyarakat dalam rangka mencapai tujuan negara (Hasan, 2005).

Arti komunikasi pemerintah di sini adalah pemerintah diasumsikan sebagai komunikator dan masyarakat sebagai komunikan, namundalamkeadaantertentu bisa sebaliknya masyarakat berada dalam posisi penyampai ide dan pemerintah berada pada posisi untuk mengamati apa yang diinginkan oleh masyarakat. Dalam keadaan seperti itu pemerintah memiliki kewenangan sekaligus tanggung jawab untuk mempertimbangkan, bahkan untuk menanggapi keinginan tersebut sesuai dengan peraturan dan ketentuan yang berlaku.

Dalam komunikasi, komunikator 
merupakan salah satu faktor yang menentukan efektivitas komunikasi. Komunikatorpemerintahmerupakansalah satu faktor yang menentukan efektivitas komunikasi. Beberapa penelitian mengidentifikasi sejumlah karakteristik yang mempengaruhi kemampuan seseorang untuk memengaruhi orang lain. Richard E. Petty dan John T. Cacioppo dalam bukunya Attitudes and Persuasion: Classic and Contemporary Approaches, mengatakan bahwa ada empat komponen yang harus ada dalam komunikator politik, yaitu kredibilitas komunikator, daya tarik komunikator, kesamaan komunikator dan kekuatan komunikator (Petty \& Cacioppo, 1996).

Elit lokal, yaitu para elit yang memerintah di tingkat daerah seperti kepala daerah memegang peranan penting dalam komunikasi pemerintahan daerah karena dia adalah pemimpin masyarakat di daerahnya yang harus memperjuangkan aspirasi dan kepentingan masyarakatnya. Kepala daerah dapat juga sebagai penghubung untuk menyerasikan kebijakan pembangunan atau kebijakan politik nasional dengan aspirasi yang lahir dan berkembang dalam masyarakat sehingga menjadi kekuatan aktual yang dapat mendorong laju pembangunan. Paradigma komunikasi dalam koordinasi pemerintahan dapat diamati dari implementasi penerapannya dalam sistem pemerintahan berdasarkan era kepemimpinan pemerintahan, yang dapat dipilah dari pijakan paradigma lama dan paradigma baru.

Gambaran singkat paradigma komunikasi pemerintahan pada GAMBAR 1, berdasarkan karakteristik kepemimpinan, karena pencarian jati diri komunikasi dalam koordinasi pemerintahan tersebut tidak pernah terlepas dari bagaimana karakteristik kepemimpinan suatu negara. Karena paradigma dipahami sebagai cara pandang yang dipengaruhi oleh situasi dan kondisi yang berkembang ketika itu. Komunikasi pemerintahan berperan dalam penanganan lingkungan kumuh di Desa Linggar. Hal ini berlandaskan pada suatu anggapan dasar bahwa setiap kegiatan yang dilaksanakan di desa oleh masyarakat yang diarahkan oleh pemerintah ditujukan untuk memperbaiki dan membangun infrastruktur lingkungan di desa Linggar. Pemerintah Daerah sedang berupaya membangun paradigma komunikasi baru yang berbasis platform kolaboratif dalam memperbaiki kualitas kawasan pemukiman kumuh, sehingga terjadi integrasi antara sektor pembangunan untuk bergerak bersama mencapai target kawasan kumuh nol (0) hektar pada tahun 2019. Berikut adalah

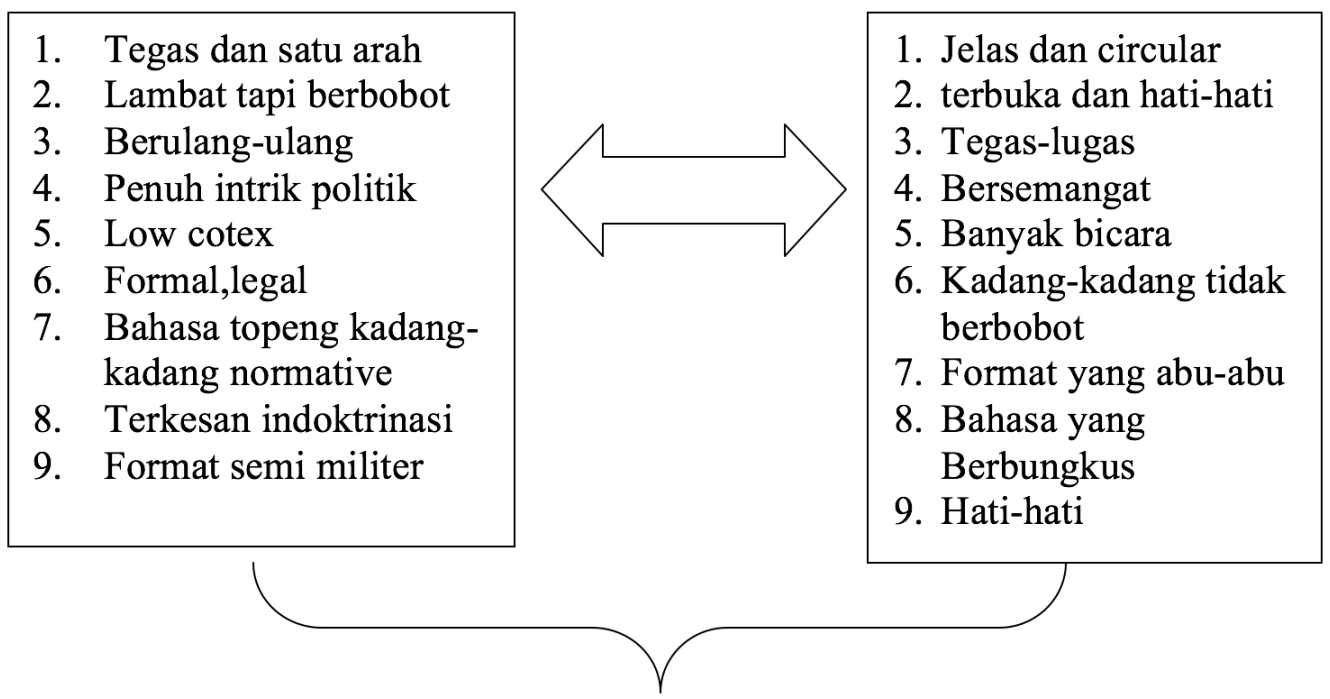

GAMBAR 1. Paradigma Komunikasi dalam Koordinasi Pemerintahan 
Indriyati Kamil. Peran Komunikasi Pemerintahan dalam Penangan Lingkungan...

TABEL 1. Sinergi Kolaborasi dan Peran Pemangku Kepentingan dalam Penanganan Lingkungan Kumuh Desa Linggar Kecamatan Rancaekek

\begin{tabular}{|c|c|c|}
\hline No & Pemangku Kepentingan (Stakeholders) & Kepentingan (Interest) \\
\hline 1 & Pemerintah Daerah Kabupaten & $\begin{array}{ll}\text { - } & \text { Penanganan dan penataan } \\
& \text { kawasan kumuh } \\
\text { - } & \text { Kesejahteraan Masyarakat }\end{array}$ \\
\hline 2 & $\begin{array}{l}\text { Badan Pengelola Lingkungan Hidup ( BPLHD ) } \\
\text { Kabupaten Bandung }\end{array}$ & $\begin{array}{l}\text { pengendalian teknis dibidang } \\
\text { pemeliharaan sarana dan } \\
\text { prasarana lingkungan } \\
\text { - } \\
\text { Pengelolaan kualitas air }\end{array}$ \\
\hline 3. & Dinas Perumahan PU & $\begin{array}{l}\text { - infrastruktur pemukiman, } \\
\text { sanitasi } \\
\text { - Infrastruktur lingkungan } \\
\text { kumuh }\end{array}$ \\
\hline 4 & $\begin{array}{l}\text { Lembaga Swadaya/Badan Keswadayaan } \\
\text { Masyarakat/Pawapeling }\end{array}$ & $\begin{array}{ll}\text { - } & \text { Pemberdayaan Masyarakat } \\
\text { - } & \text { Penguatan Kelembagaan }\end{array}$ \\
\hline 5 & Pihak BUMN,BUMD, Swasta & $\begin{array}{ll}\text { - } & \text { Pemberdayaan Bidang } \\
& \text { Ekonomi Kemasyarakatan } \\
\text { - } & \text { CSR, Program Kemitraan } \\
& \text { dan lingkungan }\end{array}$ \\
\hline 6. & Lembaga Ilmiah, Pendidikan & $\begin{array}{ll}\text { - } & \text { Peningkatan Kualitas SDM } \\
\text { - } & \text { Ilmu Pengetahuan Dan } \\
& \text { Teknologi }\end{array}$ \\
\hline
\end{tabular}

TABEL 1, peran pemangku kepentingan untuk penanganan kawasan kumuh Desa Linggar.

Dalam menangani permasalahan yang terjadi di Desa Linggar, Kecamatan Rancaekek,Pemdamelakukankomunikasi pemerintahan berbasis sinergi platform kolaboratif, dengan menggandeng unsur unsur baik dari stakeholders, swasta, industri, lembaga swadaya masyarakat serta tokoh masyarakat.

Berdasarkan TABEL 1, peran Pemda sebagai komunikator pemerintahan khususnya dalam menangani permasalahan lingkungan kumuh berupaya mengerahkan seluruh sumber sumber daya yang ada dalam mensukseskan program pembangunan lingkungannya. Pemda mendorong pihak swasta dan industri yang berdiri di area Kelurahan Linggar Kecamatan Rancaekek wajib melaksanakan perbaikan secara berkelanjutan untuk meningkatkan kinerja lingkungan, mengurangi dampak terhadap lingkungan dengan menggunakan bahan ramah lingkungan, secara berkesinambungan memberikan perlindungan lingkungan, dengan mengurangi dan mencegah pencemaran dan dampak lingkungan terhadap kawasan sekitarnya. Pemda Desa Linggar mengupayakan keterlibatan stakeholder, Organisasi Perangkat Daerah (OPD), BUMD, dunia pendidikan, dan penguatan lembaga swadaya masyarakat untuk mengharmonisasikan strategi dan membuat kesepakatan bersama (KSB) terkait solusi lingkungan agar tercipta komunikasi yang bersifat kolaboratif dalam menangani lingkungan kumuh dan kerusakan lahan pertanian serta perikanan di desa Linggar Kecamatan Rancaekek.

$\begin{array}{lr}\text { Komunikasi } & \text { Pemerintahan } \\ \text { Berdasarkan Prinsip Transparansi } & \text { Transan } \\ \text { dan Keterbukaan dalam Penanganan }\end{array}$ 


\section{Lingkungan Kumuh}

Perspektif

pemerintahan adalah gambaran komunikasi masa depan yang diterapkan dapat membawa perubahan dan menemukan formula yang paling efisien dalam pelaksanaannya. Perspektif komunikasi pemerintahan yang ideal dapat diterapkan dengan langkah-langkah berikut.

(1) Merancang mekanisme koordinasi dan komunikasi

(2) Menciptakan budaya baru

(3) Meningkatkan pemahaman aparatur terhadap tupoksi

(4) Belajar dari kesalahan

(5) Membangun SDM aparatur pemerintahan

Mekanisme koordinasi ini bervariasi baik secara vertikal, horizontal dan diagonal. Mekanisme merupakan sistem yang diterapkan supaya suatu ide atau gagasan dapat dipahami dan disetujui oleh semua pihak, merancang mekanisme koordinasi dan komunikasi dalam organisasi pemerintahan dapat dilakukan dengan pendekatan secara persuasif oleh pimpinan organisasi, melakukan sosialisasi secara terusmenerus tentang program pemerintah khususnya penanganan kawasan kumuh yang akan diterapkan, memberi kesempatan kepada semua pihak yang terlibat untuk memberikan masukan kritik dan saran untuk perbaikan ide dan gagasan khususnya dalam pengentasan lingkungan kumuh, dan melaksanakan rapat koordinasi dengan dihadiri semua pihak dalam merumuskan kebijakan terkait penataan lingkungan.

Komunikasi pemerintahan hendaknya dapat menyesuaikan dengan perkembangan pemerintahan yang saat ini berubah, dari government (penyelenggaraan pemerintahan) ke governance. Dalam hal ini terjadi perubahan interaksi dari kekuasaan dan kontrol menjadi pertukaran informasi, komunikasi dan persuasi dengan penyediaan informasi kepada masyarakat untuk dapat mengawal pemerintahan.

Membangun komunikasi pemerintahan perlu menerapkan prinsip prinsip keterbukaan, seperti yang diungkapkan GR.Terry, bahwa komunikasi yang efektif mensyaratkan adanya pendekatan faktual,dan aktual namun sebelumnya perlu pemahaman komunikasi secara komprehensif yang berlandaskan kejujuran dan hati nurani, antara lain dengan menerapkan " $4 \mathrm{C}$ " yakni : completeness, claryteness, correctness dan consicenes. Pernyataan tersebut sangat relevan dengan kondisi penyelenggaraan pemerintahan era reformasi yang mengedepankan transparansi dan keterbukaan.

Definisi permukiman kumuh berdasarkan karakteristiknya adalah lingkungan permukiman yang telah terdegradasi dalam kualitas, dan tidak memungkinkan tercapainya kehidupan yang layak bahkan cenderung membahayakan penghuninya. Infrastruktur dan sarana dasar yang kurang memadai seperti air minum, jalan, air limbah dan sampah (Sumber: Dirjen Cipta Karya).

Kawasan kumuh adalah kawasan dimana rumah dan kondisi perumahan masyarakat di daerahnya sangat buruk. Rumah dan sarana dan prasarana tidak sesuai dengan standar yang berlaku, baik kebutuhan standar, kepadatan bangunan, persyaratan rumah sehat, kebutuhan air bersih, sanitasi dan kelengkapan persyaratan infrastruktur jalan, ruang terbuka, dan kelengkapan fasilitas sosial lainnya. Berikut adalah ilustrasi Prinsip Dasar Penanganan Kawasan Kumuh Desa Linggar Rancaekek.

Ciri permukiman kumuh, seperti yang diungkapkan oleh Parsudi Suparlan (2018) adalah:
(1) Fasilitas umum yang tidak memadai atau tidak memadai. 


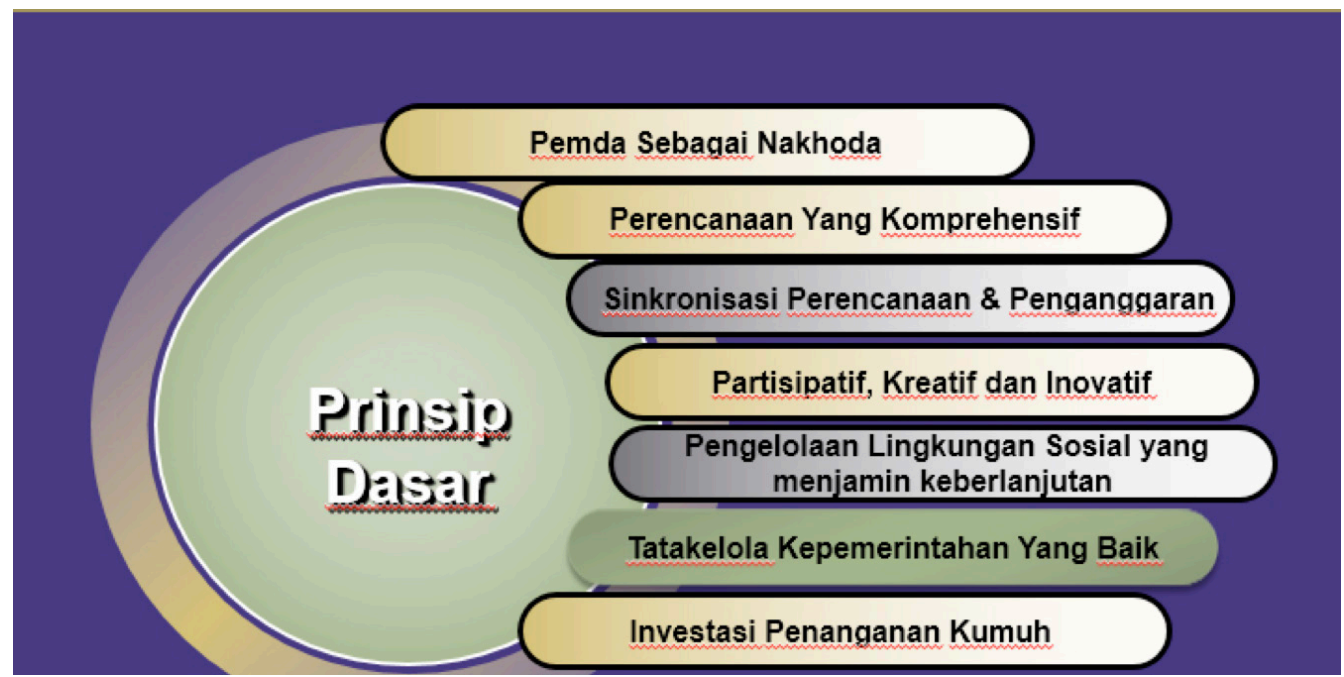

GAMBAR 2. Prinsip Dasar Penanganan Kawasan Kumuh

(2) Kondisi rumah tinggal dan permukiman dan penggunaan ruang mencerminkan penghuni yang kurang mampu atau miskin.

(3) Adanya kerapatan frekuensi dan volume tinggi dalam penggunaan ruang di pemukiman kumuh untuk mencerminkan adanya kekacauan tataruang dan ketidakberdayaan ekonomi penghuninya.

Ada dua alasan mengapa daerah kumuh terus tumbuh:

(1) Pertumbuhan penduduk

Tingkat pertumbuhan penduduk dunia di perkotaan lebih tinggi. Pertumbuhan ini mungkin berasal dari migrasi dari perkotaan ke gerhana, migrasi antarkota, dan pertumbuhan populasi alami. Beberapa faktor perampokan ke kota adalah karena faktor dorongan dan daya tarik. Faktor pendorong seperti bencana alam atau perubahan ekologis yang berakibat pada berkurangnya kesempatan kerja, sedangkan faktor penarik ke kota akibat lapangan kerja yang lebih baik, fasilitas pendidikan dan kesehatan yang baik.

(2) Tatakelola (governance)

Tatakelola pemerintahan yang salah juga dapat menyebabkan pertumbuhan kumuh. Pemerintah seringkali tidak mengakui hakhak orang miskin dan melibatkan mereka dalam proses perencanaan. Hal ini pada gilirannya mendukung pertumbuhan pemukiman kumuh. Perlambatan respons pemerintah dalam menanggapi urbanisasi juga memicu pertumbuhan kumuh. Urbanisasi membutuhkan perumahan yang terjangkau, sehingga pemerintah atau sektor swasta tidak mampu. Karena keterjangkauan yang tidak terjangkau, orang miskin mencari peluang sendiri untuk memenuhi kebutuhan hunian mereka dengan menempati lahan dan membangun gubuk mereka, atau menyewa tempat tinggal yang ada terlepas dari status tanahnya.

Pemda dalam hal ini Kepala Desa Linggar menyadari bahwa penanganan masalah pencemaran dan kerusakan lingkungan bukan hal yang mudah. Oleh karena itu, pemerintah daerah berupaya melakukan strategi operasional berupa pendampingan untuk membantu masyarakat agar mampu mengenali dan menggali potensi serta permasalahan lingkungan tempat tinggalnya. Dalam menangani masalah lingkungan kumuh, Pemda wajib menfasilitasi perencanaan prasarana lingkungan untuk warga, juga 
pemukiman dengan menggunakan konsep community action plan (CAP) atau rencana tindak komunitas. Pelaksanaan program pembangunan partisipatif melalui community action plan (CAP) ini meliputi :

(1) Sosialisasi terkait program pembangunan

(2) Pendampingan masyarakat dalam menggali permasalahan

(3) Fasilitasi penyusunan rencana tindak komunitas melalui proses perencanaan yang

(4) partisipatif; rembug warga, FGD, dll (Rinawati, 2006).

Dalam rangka pelaksanaan pembangunan bidang lingkungan, Pemda dan Kepala Desa Linggar berupaya membantu masyarakat dalam menyusun rencana induk tingkat komunitas dalam meningkatkan taraf kehidupannya, fasilitasi pembentukan paguyuban Warga Peduli Lingkungan (Pawapeling), membuat media warga dan mediasi rembug warga dengan melakukan Focus Group Discussion (FGD) yang akan menggali aspirasi dari masyarakat terkait masalah lingkungan.

Pemerintah Daerah memberikan solusi menyeluruh dalam mengatasi persoalan lingkungan di kawasan Rancaekek umumnya dan Desa Linggar khususnya. Masalah lingkungan dari hulu sampai ke hilir harus menjadi concern utama, dengan mempertemukan unsur pemerintah tingkat pusat, provinsi, dan kabupaten/kota. Pemerintah Daerah sebagai komunikator pemerintahan berupaya mensinergikan berbagai unsur yang terkait, seperti pihak industri yang bertanggung jawab dalam menyumbang limbah, warga masyarakat terdampak, LSM dan Walhi sebagai wadah untuk advokasi lingkungan agar dapat duduk bersama, berkomunikasi, berkolaborasi, dan menghasilkan kesepakatan bersama (KSB) menangani masalah pencemaran dan lingkungan sehingga dapat berjalan beriringan.

\section{SIMPULAN}

Kesimpulan yang dapat dikemukakan dalam penelitian ini menunjukkan bahwa Pemerintah, dalam hal ini Pemda Desa Linggar, sebagai penanggung jawab terhadap kesejahteraan rakyatnya memiliki tanggung jawab besar dalam upaya mewujudkan terbentuknya pelestarian lingkungan hidup, khususnya dalam menanggulangi kasus pencemaran. Kredibilitas komunikasi pemerintah daerah di Desa Linggar ditunjukkan dengan kejelasan dalam menyampaikan program dan gagasan pemerintah kepada masyarakat dalam kegiatan sosialisasi, dan program pengelolaan lingkungan kumuh di desa Linggar menggunakan prinsip "sinergi platform kolaboratif".

Dengan membangun pemahaman dan keterampilan dalam mengembangkan strategi komunikasi, membangun jaringan komunikasi dan mengembangkan media sosialisasi serta membangun komitmen pemerintah daerah sebagai nakhoda dan pemangku kepentingan dalam mensosialisasikan program penanganan lingkungan dan pengembangan jejaring komunikasi.

Dalam menyampaikan informasi tentang program peningkatan akses terhadap infrastruktur dan layanan dasar di daerah kumuh dan terdampak untuk mendukung realisasi pemukiman yang layak huni, produktif, dan berkelanjutan, pemerintah daerah Desa Linggar menggunakan prinsip keterbukaan dan transparansi dalam mewujudkan lingkungan yang bebas dari pencemaran dan hunian yang layak huni, agar warga masyarakat antusias dan tertarik untuk melakukan kegiatan pengelolaan lingkungan di wilayahnya.

$$
\text { Pemerintah Desa Linggar }
$$

mewajibkan para pengusaha industri yang berada dikawasan Desa Linggar untuk melaksanakan perbaikan lingkungan secara berkelanjutan, 
mengurangi dampak pencemaran dengan menggunakan bahan ramah lingkungan, secara berkesinambungan memberikan program perlindungan lingkungan, dan memberikan program pemberdayaan masyarakat secara berkesinambungan.

$$
\text { Pada pelaksanaan program }
$$
penanganan lingkungan kumuh, Kepala Desa melakukan komunikasi dan mendorong peran warga masyarakat sebagai relawan pemukiman yang mempunyai posisi strategis dan penting dalam upayanya sebagai agen perubahan di wilayahnya, antara lain: Pertama, sebagai agen sosialisasi program di tingkat masyarakat, akan pentingnya pencegahan kumuh dan penanganan pemukiman kumuh di wilayahnya. Kedua, sebagai agen perubahan sikap dan perilaku dalam upaya menciptakan pemukiman layak huni dan bebas pemukiman kumuh skala lingkungan di wilayahnya. Ketiga, membangun kolaborasi antarpelaku program, dalam upaya percepatan penanganan kumuh yang dilakukan sejak tahap perencanaan, pelaksanaan, pemantauan dan evaluasi, pemanfaatan, pemeliharaan serta keberlanjutan di wilayahnya. Keempat, mampu mengembangkan media warga dalam upaya pencegahan dan penanganan permukiman kumuh di wilayahnya. Dukungan dari masyarakat diperoleh dari keterlibatan dan peran aktif masyarakat dan relawan dalam usaha pencegahan dan penanganan lingkungan kumuh yang diakibatkan pencemaran limbah industri.

Pemerintah Daerah, dalam hal ini Kepala Desa Linggar, Kecamatan Rancaekek, melakukan komunikasi pemerintahan dengan melibatkan pemangku kepentingan dan partisipasi aktif masyarakat serta membangun dan memperkuat peran lembaga daerah dalam penanganan perkampungan kumuh, dengan membentuk kelompok pranata sosial, di antaranya; Paguyuban Warga Peduli Lingkungan (Pawapeling), menfasilitasi rembug warga, melakukan fokus group diskusi untuk bekerja sama merumuskan dan melaksanakan program yang akan dilaksanakan bersama. Pawepeling memiliki peran penting dan strategis terutama dalam rangka mengadvokasi dan meningkatkan kualitas permukiman di Kelurahan Linggar, bekerja dengan melibatkan sektor swasta dan masyarakat.

Oleh karena itu, diperlukan adanya persamaan visi, pola pikir serta pola tindakan, antara pemerintah, pihak swasta dan masyarakat, dalam menangani masalah lingkungan kumuh di daerahnya. Saluran media komunikasi yang digunakan oleh Pemerintah Daerah Kelurahan Linggar dalam melaksanakan program pengelolaan lingkungan kumuh adalah dengan menggunakan media warga, diskusi kelompok terarah untuk memecahkan masalah lingkungan di desa.

\section{DAFTAR PUSTAKA}

Arifin, Anwar. (2008). Ilmu Komunikasi Suatu Pengantar Ringkas. Jakarta: PT. Raja Grafindo Persada.

Hadari, Nawawi. (2005). Metode Penelitian Bidang Sosial. Yogyakarta: Gadjah Mada University Press.

Hasan, Erliana. (2005). Komunikasi Pemerintahan. Refika Aditama: Bandung.

Kriyantono, Rachmat. (2007). Teknik Praktis Riset Komunikasi. Jakarta: Prenada Media Group.

Parsudi, Suparlan. (1984). Kebudayaan Kemiskinan, dalam Kemiskinan di Perkotaan, Jakarta, Yayasan Obor Indonesia - Sinar Harapan

Rinawati, Rini. (2006). Komunikasi dan Pembangunan Partisipatif, Jurnal Komunikasi MediaTor Volume 7 No.2. Halaman 175-184.

Petty, Richard E. \& Cacioppo, John T. (1996). Attitudes and Persuasion: Classic and Contemporary Approaches, USA: Avalon Publishing. 